\title{
Trends in mean monthly maximum and minimum surface wind speeds in the coterminous United States, 1961 to 1990
}

\author{
Katherine Klink* \\ Department of G eography, 414 Social Sciences Bldg., University of Minnesota, M inneapolis, Minnesota 55455, USA
}

\begin{abstract}
Mean monthly wind speed maxima and minima at 187 and 176 stations (respectively) in the coterminous United States are examined for 1961 to 1990. Both maximum and minimum winds are highest in spring and lowest during the summer. Reduced speeds occur in the western United States, where surface topography is most variable, and in the southeast, which is dominated by high pressure during much of the year. The central and the northeastern United States, which have more gentle topography and are near common storm tracks, have the highest maximum and minimum winds. Leastsquares regression lines fit to the $30 \mathrm{yr}$ time series show that, on balance, mean monthly maximum winds are increasing within the United States and mean monthly minima are decreasing. When averaged over all stations, the increase in maximum winds is largest in summer and autumn, with decreases occurring from February through May. Minimum speeds decrease in all months of the year, with the smallest reductions in summer and the largest in spring. In absolute terms the increase in maximum winds is larger than the decrease in minima, but in percentage terms the change in minimum speeds is larger than the change in maxima. Possible causes of the observed trends in maximum and minimum surface wind speeds include hemispheric temperature trends, changes in cyclone and anticyclone frequency, urbanization effects, and instrumentation and observation biases.
\end{abstract}

KEY WORDS: Surface wind speed · Wind speed trends · United States climate

\section{INTRODUCTION}

Much effort has focused on evaluating how surface air temperature has varied over the history of instrumental measurements. Most studies have identified an increase in mean surface temperatures over the last century (e.g. J ones 1994, Nicholls et al. 1996). In addition, minimum (usually nighttime) temperatures are increasing more rapidly than the maxima, even after correcting for urban heat island biases (e.g. Karl et al. 1993, Easterling et al. 1997). Such large-scale changes in global and hemispheric temperature patterns may manifest themselves in other parts of the climate system. In this paper I explore the record from 1961 to 1990 of monthly mean maximum and minimum surface wind speeds in the coterminous United States. Because

*E-mail: klink@atlas.socsci.umn.edu wind speed is, in part, a function of the pressure gradient, which in turn is related to temperature, it is possible that changes in surface temperature may produce systematic changes in surface winds. This exploratory analysis focuses on maximum and minimum speeds to evaluate whether long-term trends in these fields are similar to those observed for maximum and minimum surface temperatures. Other factors that may affect maximum and minimum wind speed trends also are discussed, including changes in synoptic-scale activity, urbanization effects, and biases in the observational record.

\section{WIND DATA SOURCE}

Monthly mean time series were computed from hourly and 3-hourly surface wind observations from 1961 to 1990 at 187 stations in the coterminous United 
Table 1. Stations (city and state) used in the wind speed analyses. *Stations excluded from minimum wind speed analyses due to consistent omission of nighttime observations

\begin{tabular}{|c|c|c|}
\hline Birmingham AL & Boston MA & Oklahoma City OK \\
\hline Huntsville AL & Worcester MA & Tulsa OK \\
\hline Mobile AL & Baltimore MD & Astoria OR \\
\hline Montgomery AL & Caribou ME* & Eugene OR \\
\hline Fort Smith AR & Portland ME & Medford OR \\
\hline Little Rock AR & Alpena MI & Pendleton OR \\
\hline Flagstaff AZ & Detroit MI & Portland OR \\
\hline Phoenix AZ & Flint MI & Salem OR \\
\hline Tucson AZ & Grand Rapids MI & Allentown PA \\
\hline Bakersfield CA* & Lansing MI & Erie PA \\
\hline Fresno CA & Muskegon MI & Philadelphia PA \\
\hline Long Beach CA & Sault Ste. M arie MI & Pittsburgh PA \\
\hline Los Ángeles CA & Duluth MN & Wilkes-Barre PA \\
\hline Sacramento CA & International Falls MN & Williamsport PA \\
\hline San Diego CA & Minneapolis M N & Providence RI \\
\hline San Francisco CA & Rochester M N & Charleston SC \\
\hline Santa Maria CA* & St. Cloud M N* & Columbia SC \\
\hline Alamosa CO* & Columbia MO & Huron SD \\
\hline Colorado Springs CO & Kansas City MO & Rapid City SD \\
\hline Grand J unction CO & St. Louis MO & Sioux Falls SD \\
\hline Pueblo CO* & Springfield MO & Bristol TN \\
\hline Bridgeport CT* & J ackson MS & Chattanooga TN \\
\hline Hartford CT & Meridian MS & Knoxville TN \\
\hline Wilmington DE & Billings MT & Memphis TN \\
\hline Daytona Beach FL & Glasgow MT & Nashville TN \\
\hline J acksonville FL & Great Falls MT & Abilene TX \\
\hline Key West FL & Helena MT & Amarillo TX \\
\hline Miami FL & Kalispell MT & Austin TX \\
\hline Tallahasse FL & Missoula MT & Brownsville TX \\
\hline Tampa FL & Asheville NC & Corpus Christi TX \\
\hline West Palm Beach FL & Cape Hatteras NC & El Paso TX \\
\hline Augusta GA & Charlotte NC & Fort Worth TX \\
\hline Athens GA & Greensboro NC & Houston TX \\
\hline Atlanta GA & Raleigh NC & Lubbock TX \\
\hline Columbus GA & Wilmington NC & Midland TX \\
\hline Macon GA & Bismarck ND & Port Arthur TX \\
\hline Savannah GA & Fargo ND & San Angelo TX \\
\hline Des Moines IA & Grand Island NE & San Antonio TX \\
\hline Sioux City IA & Norfolk NE* & Victoria TX \\
\hline Waterloo IA & North Platte NE & Waco TX \\
\hline Boise ID & Omaha NE & Wichita Falls TX \\
\hline Pocatello ID & Scottsbluff NE & Cedar City UT \\
\hline Chicago IL & Concord NH & Salt Lake City UT \\
\hline Moline IL & Atlantic City NJ & Lynchburg VA* \\
\hline Peoria IL & Newark NJ & Norfolk VA \\
\hline Rockford IL & Albuquerque NM & Richmond VA \\
\hline Springfield IL & Elko NV & Roanoke VA \\
\hline Evansville IN & Ely NV & Burlington VT \\
\hline Fort Wayne IN & Las Vegas NV & Olympia WA \\
\hline Indianapolis IN & Reno NV & Seattle WA \\
\hline South Bend IN & Winnemucca NV & Spokane WA \\
\hline Dodge City KS & Albany NY & Yakima WA \\
\hline Goodland KS & Binghamton NY & Green Bay WI \\
\hline Topeka KS & Buffalo NY & La Crosse WI \\
\hline Wichita KS & Rochester NY & Madison WI \\
\hline Covington $\mathrm{KY}$ & Syracuse NY & Milwaukee WI \\
\hline Lexington $\mathrm{KY}$ & Akron OH & Charleston WV \\
\hline Louisville KY & Cleveland $\mathrm{OH}$ & Elkins WV* \\
\hline Baton Rouge LA & Columbus $\mathrm{OH}$ & Casper WY \\
\hline Lake Charles LA & Dayton $\mathrm{OH}$ & Cheyenne WY \\
\hline New Orleans LA & Mansfield $\mathrm{OH}^{*}$ & Lander WY \\
\hline Shreveport LA & $\begin{array}{l}\text { Toledo } \mathrm{OH} \\
\text { Youngstown } \mathrm{OH}\end{array}$ & Sheridan WY \\
\hline
\end{tabular}

States (NREL [National Renewable Energy Laboratory] 1993) (Table 1). Standard National Weather Service (NWS) procedure during this period was to report wind speed as the average speed that occurred over a $1 \mathrm{~min}$ interval (US Department of Commerce 1963, $1970,1988)$. Average speed was not to be determined during a peak or lull in gusty winds. When wind speeds were less than the starting speed of the (standard 3-cup) anemometer (apparently about $3 \mathrm{knots}$, or $1.5 \mathrm{~m} \mathrm{~s}^{-1}$ ) or if instrumentation was unavailable, observers were instructed to estimate the speed using the Beaufort scale (US Department of Commerce 1963, 1970, 1988). Quality of the wind data was presumed to be good because the observations in the NREL data set had been checked according to standard meteorological quality control procedures, including conformance to established observing practice, internal consistency, and comparison against defined limits (NREL 1992; see also DeGaetano 1997).

For this study I used only those stations with wind data and station instrument histories spanning the entire $30 \mathrm{yr}$ period. Station histories (available in NOAA 1993) showed that most stations had instrument moves and had changes in anemometer heights, which ranged between about 20 and $70 \mathrm{ft}$ (6.1 and $21.3 \mathrm{~m}$ ). (Forty-nine-about $26 \%$ - of the 187 stations had no changes in measurement height over the period of record.) The most common measurement height was $6.1 \mathrm{~m}$, and I standardized all hourly and 3-hourly wind speeds to this height using the 1/7 power law (Peterson \& Hennessey 1978). I did not account for stability effects in the height corrections (e.g. Touma 1977) because data were not available to implement such corrections.

Most of the 187 stations had few missing hourly or 3-hourly observations (Table 2), with missing data occurring randomly over the $30 \mathrm{yr}$ period. Some stations were missing more than $10 \%$ of the data because wind speeds were recorded only during daylight hours for large portions of the record. Because the lowest wind speeds typically occur at night, mean monthly minima were computed only for the 176 stations with $24 \mathrm{~h}$ observation schedules (Table 1).

Height-corrected hourly and 3-hourly wind data were used to identify the maximum and minimum wind speed for each day from 1961 
Table 2. Percentage of missing hourly or 3-hourly observations at the 187 stations in the wind data set

\begin{tabular}{|cc|}
\hline$\%$ of missing observations & Number (\%) of stations \\
\hline 0 & $105(56)$ \\
$0.1-1$ & $55(29)$ \\
$1.1-3$ & $7(4)$ \\
$3.1-5$ & $4(2)$ \\
$5.1-10$ & $5(3)$ \\
$10.1-15$ & $3(2)$ \\
$15.1-20$ & $2(1)$ \\
$20.1-30$ & $2(1)$ \\
$30.1-40$ & $4(2)$ \\
\hline
\end{tabular}

to 1990 (i.e. I assigned the maximum wind speed on J anuary 1, 1961, as the fastest hourly or 3-hourly speed reported on that day). Daily maxima (and minima) then were averaged to derive the mean maximum (and minimum) wind speed for each month. I used hourly and 3-hourly data together to determine the monthly means, which may introduce some bias in the estimates (cf. DeGaetano 1998). The bias is conservative because 3-hourly data cannot overestimate maximum speeds or underestimate minimum speeds that are identified from hourly records. I evaluated the effect of this bias for the 3 stations in the data set that had hourly wind reports throughout the $30 \mathrm{yr}$ period: Los Angeles CA, Salt Lake City UT, and Philadelphia PA. For each of these stations I used 3-hourly data from 1966-1980 to recalculate monthly mean maxima and minima; this $15 \mathrm{yr}$ span is slightly longer than the typical duration of 3-hourly reports at most other stations in the data set. At Los Angeles, Salt Lake City, and Philadel phia, monthly maxima based on 3-hourly data were underestimated by 0.2 to $0.3 \mathrm{~m} \mathrm{~s}^{-1}$ (on average), and monthly minima were overestimated on average by 0.1 to $0.2 \mathrm{~m} \mathrm{~s}^{-1}$.

I assumed that instrument moves (without height changes) did not affect wind speed readings, although this may not be correct if anemometers were repositioned in areas with different roughness characteristics. However, time series of monthly mean wind speed maxima and minima for several randomly selected stations having instrument moves showed no obvious discontinuities corresponding to times of relocation.

\section{TRENDS IN UNITED STATES MEAN MAXIMUM AND MINIMUM WIND SPEEDS}

\subsection{M aximum winds}

Mean maximum wind speeds generally are highest in the central and northeastern United States, and in some locations in the west where topographic channel- ing may enhance surface winds (Fig. 1). Other locations in the west show lower maximum speeds because of the more varied topography. Low maximum wind speeds in the southeastern United States reflect the dominance of high pressure in this area during most months of the year (Klink 1999). For most locations, maximum winds are faster in winter and spring and slower during the summer and autumn. High summertime maxima at some western intermountain locations is related to the development of the summertime thermal low.

Thirty-year trends in mean maximum wind speeds (computed from ordinary least-squares regression) are positive for most stations across the country, though some show negative trends (Figs. $2 \& 3$, Table 3). In general, positive trends are largest and occur at more stations in summer, autumn, and winter, with November having the largest number of increasing maxima (Table 4). Spring months have an almost equal frequency of stations with positive and negative trends in maximum speeds, with negative trends slightly more numerous. In his study of wind power in the midwestern United States, Shein (1995), using the same wind data set but averaging over years rather than months, found similar results.

Some of the larger percentage increases (or decreases) in maximum speeds occur at sites with low mean maxima, but stations with higher maxima also show substantial - mostly positive $-30 \mathrm{yr}$ trends. M ost stations have experienced increasing maxima throughout the year, with other sites showing increases in some months and decreases in others. A few stations have decreasing maximum speeds for all months (e.g. Pendleton OR, EI Paso TX, Tampa FL). On average, mean maximum wind speeds are increasing in the summer, autumn, and winter, and are decreasing in the spring (Table 5).

\subsection{M inimum winds}

M ean minimum wind speeds are low throughout the year: most are less than $3 \mathrm{~m} \mathrm{~s}^{-1}$. M onthly minima usually are smallest in the summer and are larger in winter and spring, with stations in the northern tier of states showing the largest seasonal variation (Fig. 4). Due to the higher and more variable topography in the western United States, minima there typically are small. Minimum winds are low in the southeast because of the dominance of high pressure, which also produces the region's low mean maxima. M inimum winds are higher in the central and northeastern United States, where the topography is flat to gently rolling and where cyclone and anticyclone passage is more frequent (Changnon et al. 1995). 


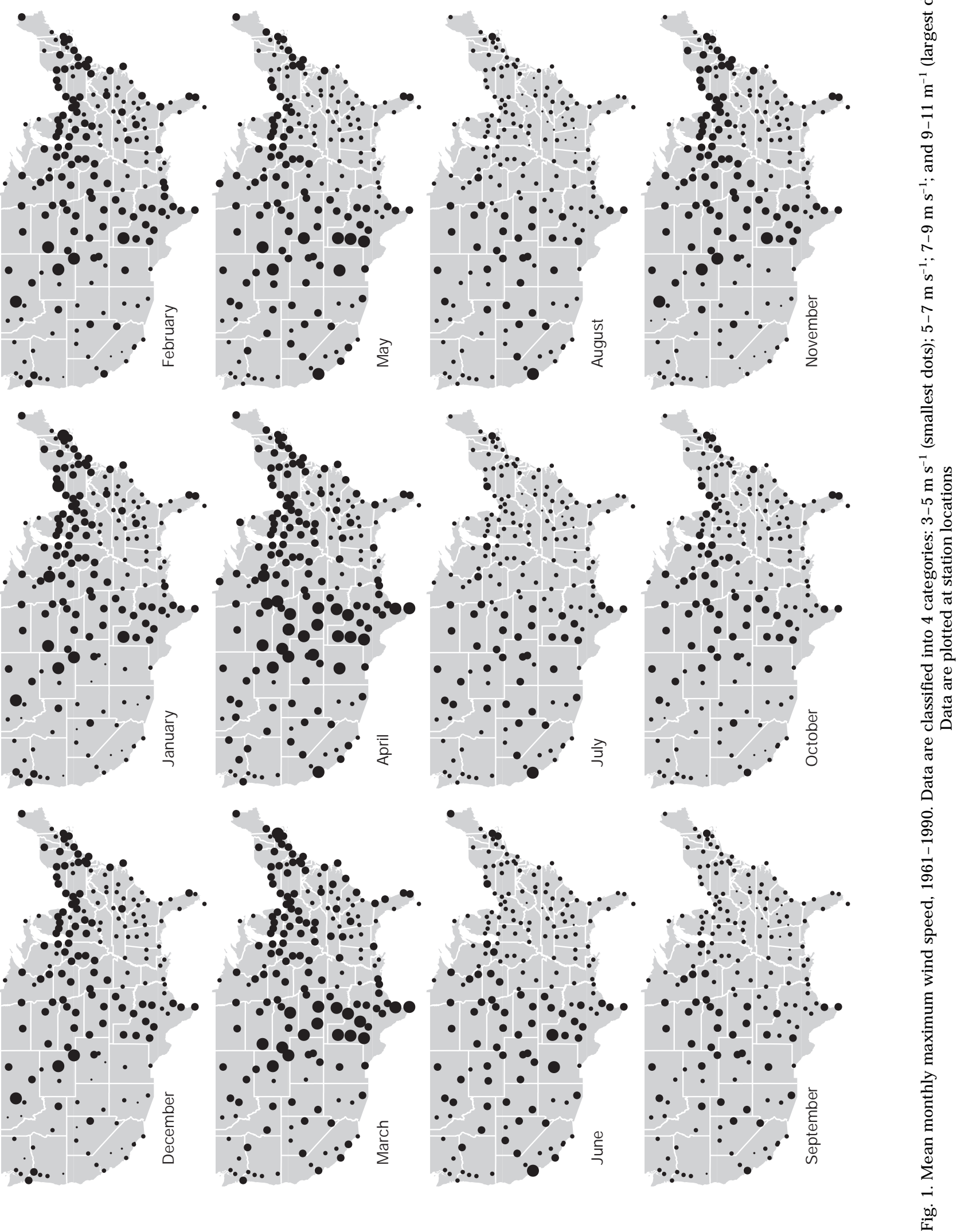




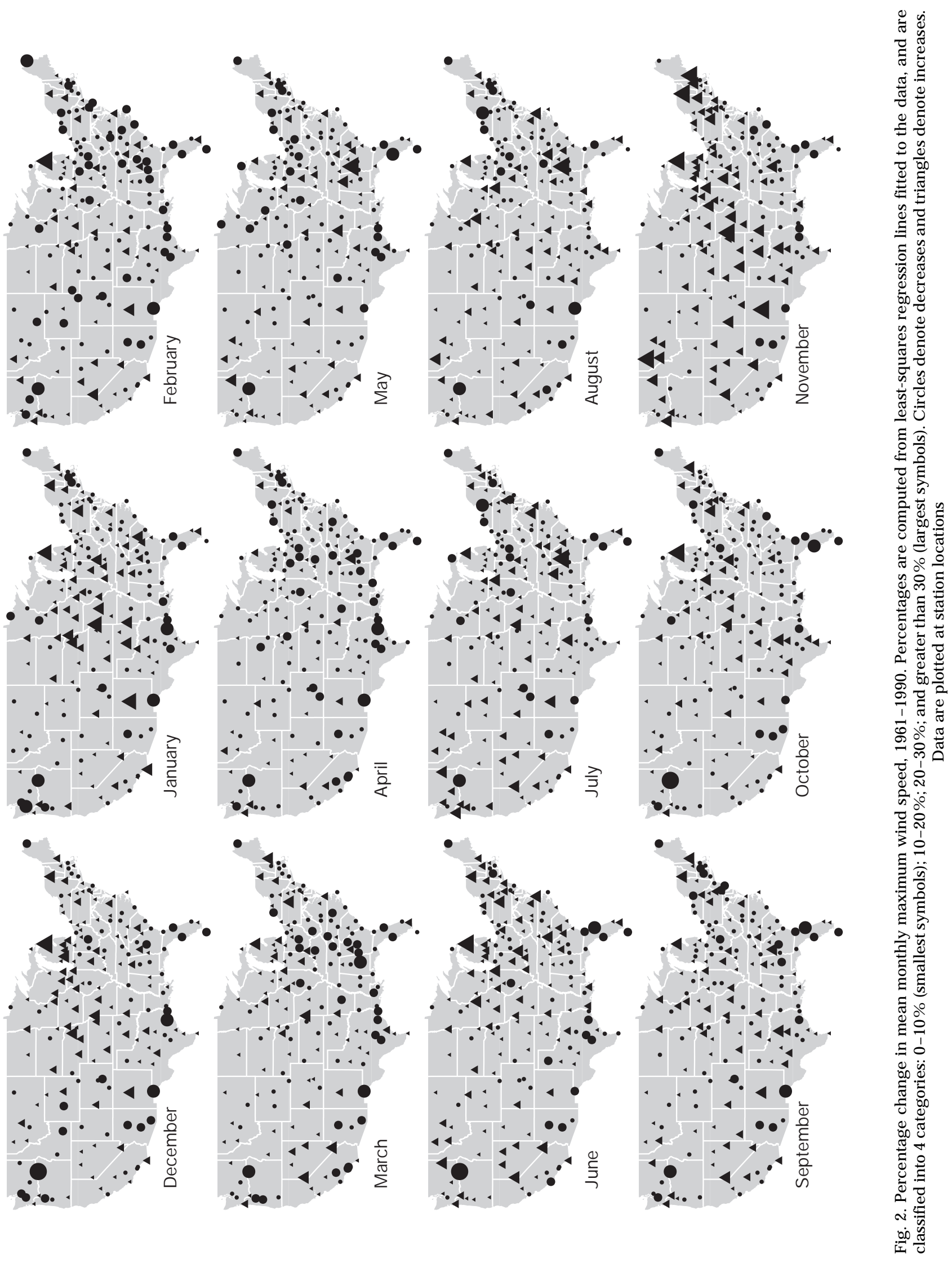



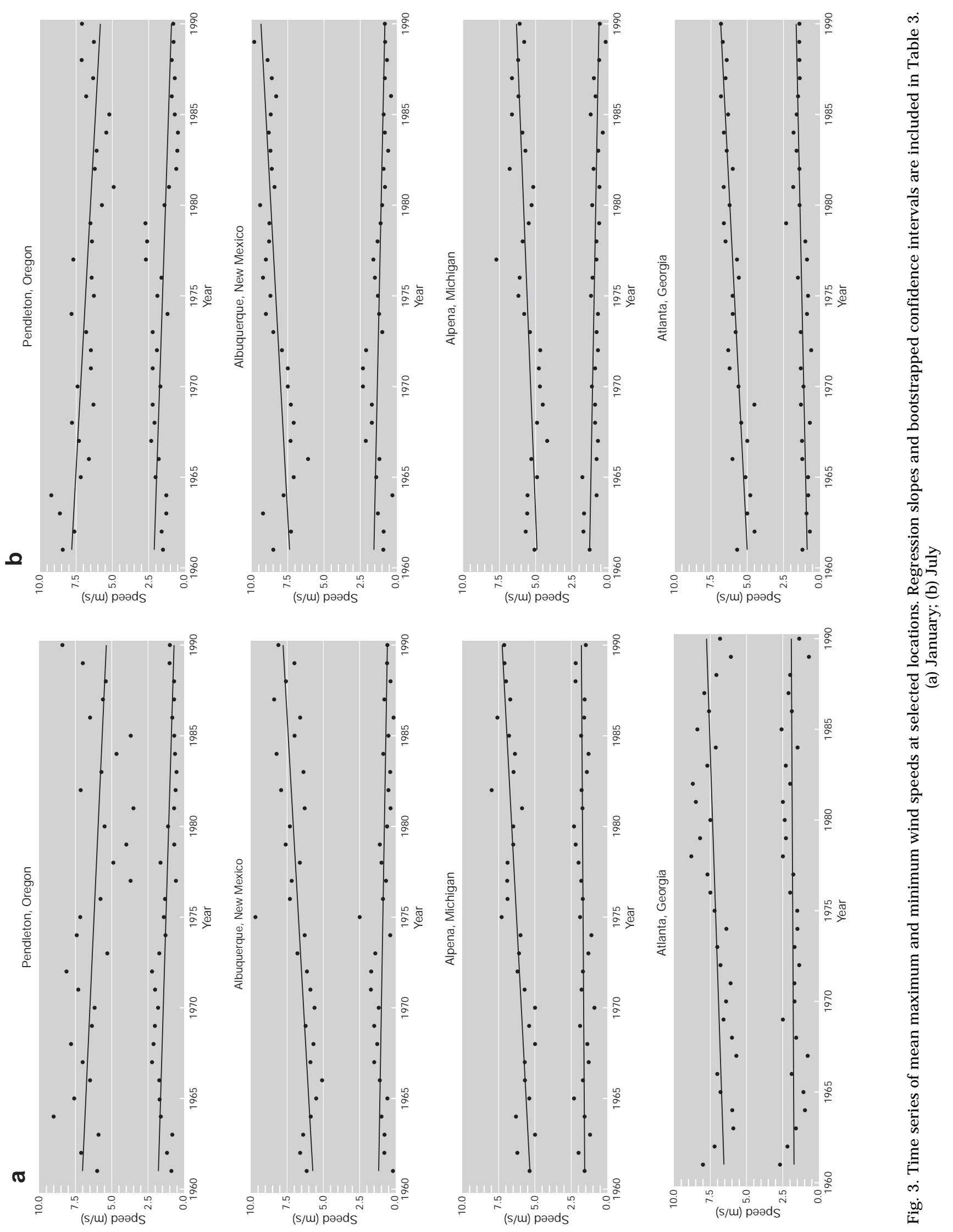

ज्ञ 
Table 3. Observed regression slopes $\left(\mathrm{m} \mathrm{s}^{-1} \mathrm{yr}^{-1}\right)$ and bootstrapped confidence intervals (Efron \& Tibshirani 1986) for J anuary and J uly maximum (max) and minimum ( $\mathrm{min}$ ) wind speed trends shown in Fig. 3. Bootstrap statistics are based on 1000 bootstrapped samples

\begin{tabular}{|c|c|c|c|c|}
\hline & $\begin{array}{l}\text { Observed } \\
\text { slope }\end{array}$ & $\begin{array}{l}\text { Average bootstrapped } \\
\text { slope }\end{array}$ & $\begin{array}{c}\text { Lower 95\% } \\
\text { confidence limit }\end{array}$ & $\begin{array}{c}\text { Upper } 95 \% \\
\text { confidence limit }\end{array}$ \\
\hline \multicolumn{5}{|l|}{ Pendleton OR } \\
\hline J an max trend & -0.0558 & -0.0003 & -0.0503 & 0.0487 \\
\hline J an min trend & -0.0370 & -0.0001 & -0.0196 & 0.0198 \\
\hline Jul max trend & -0.0685 & -0.0007 & -0.0356 & 0.0328 \\
\hline ul min trend & -0.0416 & 0.0003 & -0.0239 & 0.0230 \\
\hline \multicolumn{5}{|c|}{ Albuquerque NM } \\
\hline J an max trend & 0.0699 & 0.0011 & -0.0347 & 0.0362 \\
\hline J an min trend & -0.0201 & 0.0002 & -0.0165 & 0.0168 \\
\hline J ul max trend & 0.0676 & 0.0006 & -0.0302 & 0.0303 \\
\hline J ul min trend & -0.0261 & 0.0001 & -0.0180 & 0.0190 \\
\hline \multicolumn{5}{|l|}{ Alpena MI } \\
\hline J an max trend & 0.0653 & 0.0003 & -0.0268 & 0.0276 \\
\hline J an min trend & 0.0079 & -0.0003 & -0.0121 & 0.0116 \\
\hline J ul max trend & 0.0481 & 0.0002 & -0.0235 & 0.0253 \\
\hline J ul min trend & -0.0230 & 0.0002 & -0.0116 & 0.0124 \\
\hline \multicolumn{5}{|l|}{ Atlanta G A } \\
\hline J an max trend & 0.0418 & -0.0002 & -0.0285 & 0.0293 \\
\hline J an min trend & 0.0067 & -0.0006 & -0.0194 & 0.0181 \\
\hline J ul max trend & 0.0631 & 0.0002 & -0.0225 & 0.0233 \\
\hline ul min trend & 0.0263 & 0.0000 & -0.0139 & 0.0139 \\
\hline
\end{tabular}

Table 4. Number and percentage of stations having positive and negative linear trends in mean maximum wind speed, by month

\begin{tabular}{|lrr|}
\hline Month & $\begin{array}{c}\text { Number (\%) of stations } \\
\text { with positive trends }\end{array}$ & $\begin{array}{r}\text { Number (\%) of stations } \\
\text { with negative trends }\end{array}$ \\
\hline Jan & $103(55)$ & $84(45)$ \\
Feb & $79(42)$ & $108(58)$ \\
Mar & $93(50)$ & $94(50)$ \\
Apr & $71(38)$ & $116(62)$ \\
May & $92(49)$ & $95(51)$ \\
Jun & $127(68)$ & $60(32)$ \\
Jul & $122(65)$ & $65(35)$ \\
Aug & $109(58)$ & $78(42)$ \\
Sep & $95(51)$ & $92(49)$ \\
Oct & $104(56)$ & $83(44)$ \\
Nov & $132(71)$ & $55(29)$ \\
Dec & $112(60)$ & $75(40)$ \\
\hline
\end{tabular}

Between 1961 and 1990, most stations showed a decrease in mean minimum wind speeds (Figs. $3 \& 5$, Table 3). The percentage decrease is larger in winter and spring than in summer and autumn; April has the most stations with decreasing minima, and J uly and November have the fewest (Table 6). Sites in the western and the southeastern United States exhibit the largest percentage decreases, due in part to their low mean minima (Fig. 4), but other locations with higher minima also have substantial decreases in
Table 5. Thirty-year linear trends $\left(\mathrm{m} \mathrm{s}^{-1} \mathrm{yr}^{-1}\right)$ in mean maximum, mean minimum, and monthly mean wind speed in the United States. Average trends were computed by averaging the slopes of ordinary least-squares regression lines fitted to data at all available stations

\begin{tabular}{|lccc|}
\hline Month & $\begin{array}{c}\text { Average trend } \\
\text { for mean } \\
\text { maxima } \\
\text { (187 stations) }\end{array}$ & $\begin{array}{c}\text { Average trend } \\
\text { for mean } \\
\text { minima } \\
\text { (176 stations) }\end{array}$ & $\begin{array}{c}\text { Average trend } \\
\text { for monthly } \\
\text { mean } \\
\text { (176 stations) }\end{array}$ \\
\hline Jan & 0.0058 & -0.0139 & -0.0042 \\
Feb & -0.0028 & -0.0128 & -0.0073 \\
Mar & -0.0006 & -0.0137 & -0.0069 \\
Apr & -0.0062 & -0.0198 & -0.0133 \\
May & -0.0011 & -0.0162 & -0.0082 \\
J un & 0.0092 & -0.0104 & 0.0005 \\
Jul & 0.0070 & -0.0090 & -0.0001 \\
Aug & 0.0047 & -0.0109 & -0.0025 \\
Sep & 0.0028 & -0.0129 & -0.0042 \\
Oct & 0.0040 & -0.0128 & -0.0029 \\
Nov & 0.0162 & -0.0068 & 0.0047 \\
Dec & 0.0055 & -0.0124 & -0.0031 \\
\hline
\end{tabular}

minimum speeds over this period. A few stations show consistent increases in mean minimum wind speeds for most months, including Las Vegas and Winnemucca NV, Rochester MN, Burlington VT, and Atlanta $\mathrm{GA}$; other sites have minima that increase in some months and decrease in others. The majority of stations across the country show decreasing minimum 


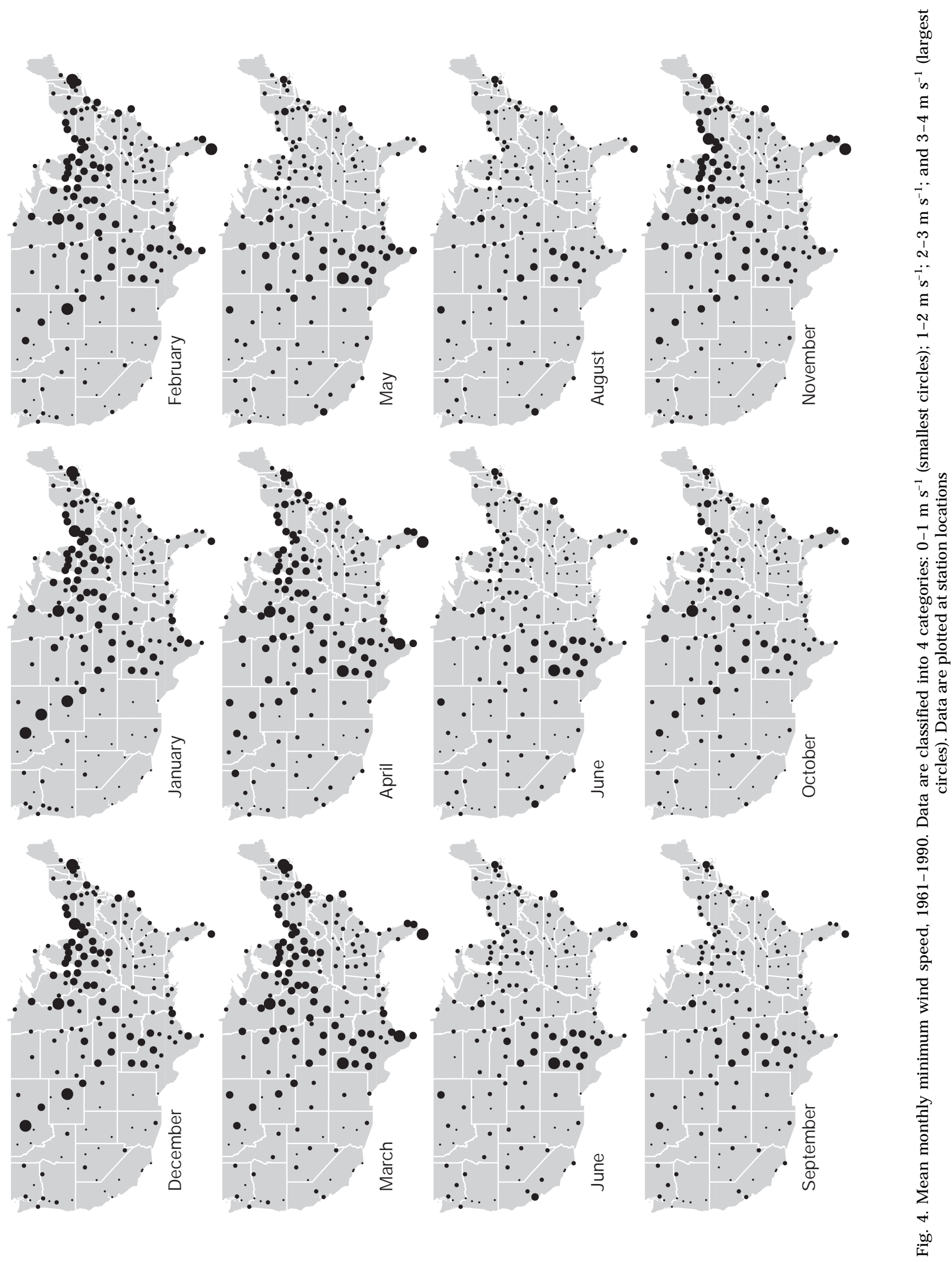




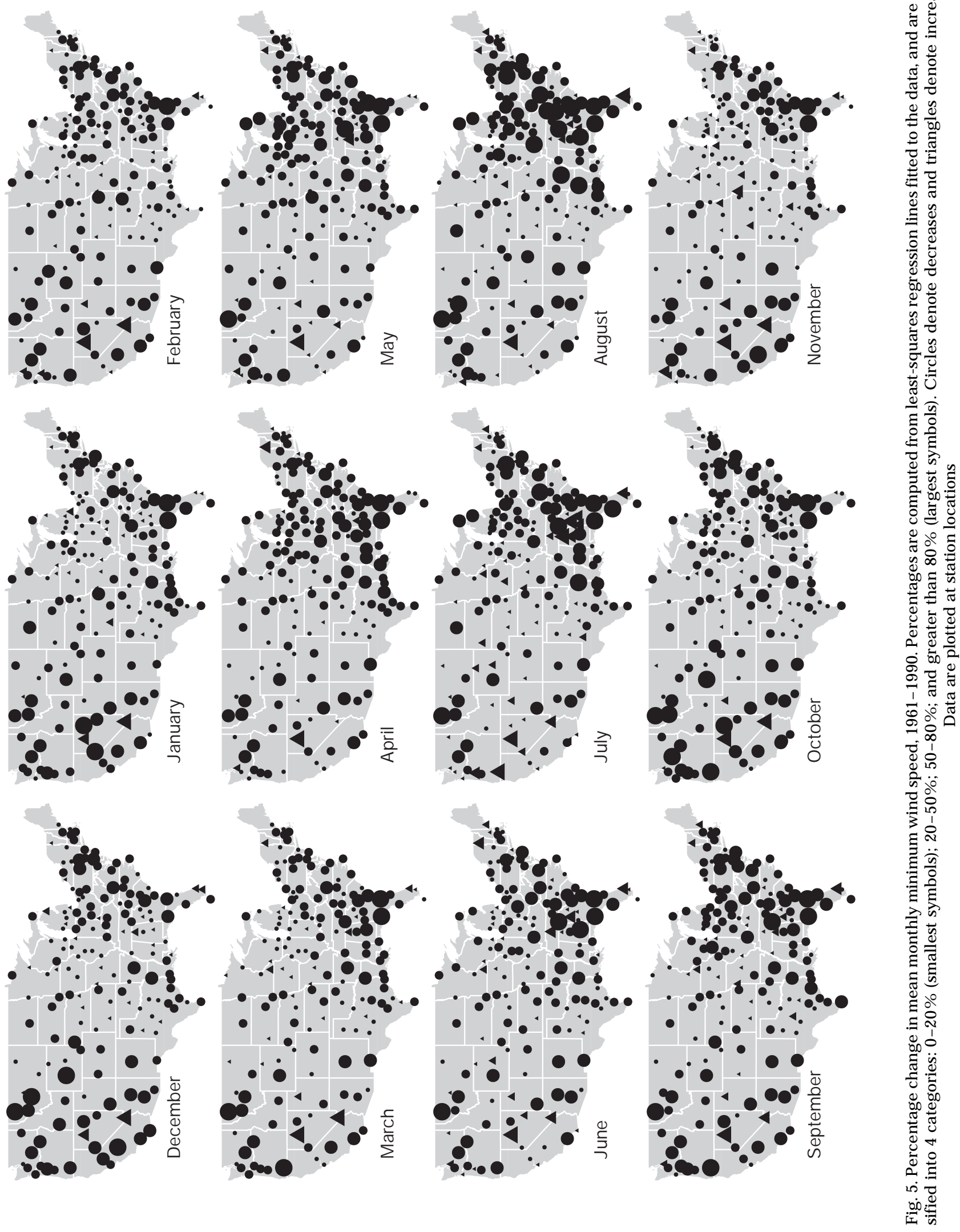


Table 6. Number and percentage of stations having positive and negative linear trends in mean minimum wind speed, by month

\begin{tabular}{|lcc|}
\hline Month & $\begin{array}{c}\text { Number (\%) of } \\
\text { stations with } \\
\text { positive trends }\end{array}$ & $\begin{array}{c}\text { Number (\%) of } \\
\text { stations with } \\
\text { negative trends }\end{array}$ \\
\hline Jan & $26(15)$ & $150(85)$ \\
Feb & $27(15)$ & $149(85)$ \\
Mar & $27(15)$ & $149(85)$ \\
Apr & $13(7)$ & $163(93)$ \\
May & $23(13)$ & $153(87)$ \\
Jun & $40(23)$ & $136(77)$ \\
Jul & $51(29)$ & $125(71)$ \\
Aug & $39(22)$ & $138(78)$ \\
Sep & $29(16)$ & $147(84)$ \\
Oct & $22(12)$ & $154(88)$ \\
Nov & $50(28)$ & $126(72)$ \\
Dec & $29(16)$ & $147(84)$ \\
\hline
\end{tabular}

wind speeds over most of the year (Table 6). In absolute terms the decrease in minimum wind speeds is smaller than the increase in maxima because the minimum is zero-limited, but linear trends in minimum speeds are as much as an order of magnitude larger than those for the maxima (Table 5). Shein's (1995) annually averaged minimum trends for stations in the midwestern United States are similar to these monthly trends.

The original hourly and 3-hourly data for 1961 to 1990 show that for the majority of stations with decreasing trends in mean minimum wind speeds, there is an increasing frequency of calm winds, especially at night. Similarly, stations with increasing minima show a decrease in the frequency of calms, particularly at night. For a given station there is a close correspondence between months with decreasing (increasing) minima and months having an increasing (decreasing) frequency of nighttime calms.

\section{FACTORS AFFECTING SURFACE WIND SPEED}

\subsection{Surface temperature effects}

Wind speed is related to the surface pressure gradient, which in turn is a function of the temperature gradient. The observed century-scale increase in mean temperatures, particularly the enhanced warming at higher latitudes compared to the tropics (e.g. Easterling et al. 1997), could decrease the pressure gradient over the United States and reduce wind speeds. Coupling the geostrophic wind equation with the ideal gas law provides a means to evaluate the relationship between wind speed $(V)$ and the temperature gradient $(\Delta T / \Delta x)$ :

$$
\mathrm{V}=\frac{\mathrm{R}}{f} \frac{\Delta \mathrm{T}}{\Delta \mathrm{x}}
$$

where $\mathrm{R}$ is the gas constant and $\mathrm{f}$ is the Coriolis parameter. To determine how the temperature must change $[\Delta(\Delta T)]$ to produce a given change in wind speed $(\Delta \mathrm{V})$, take the difference of both sides of Eq. (1) and rearrange:

$$
\Delta(\Delta \mathrm{T})=\left(\frac{f}{\mathrm{R}} \Delta \mathrm{x}\right) \Delta \mathrm{V}
$$

I computed average seasonal (DJ F, M A M , J J A, SON) wind speed changes between 1961 and 1990 from the trends in Table 5. Inserting these estimates of $\Delta \mathrm{V}$ into Eq. (2), I found that to account for the observed decreases in average wind speeds the wintertime equator-to-pole temperature gradient (EPG) must decrease by about $0.5^{\circ} \mathrm{C}$; the spring EPG must decrease by about $0.9^{\circ} \mathrm{C}$; and the summer and autumn EPGs must decrease by slightly less than $0.1^{\circ} \mathrm{C}$. These calculations are fairly simplistic, but the computed changes in EPG are broadly consistent with observed temperature trends (cf. Nicholls et al. 1996).

Another way that temperature changes may affect surface winds is by altering the near-surface vertical temperature gradient and thus the turbulent mixing. An increase in surface maximum temperatures (which occur mostly during the day) would steepen the near-surface lapse rate and promote mixing with faster winds aloft, thereby increasing wind speeds at the surface. The observed increase in maximum speeds supports this connection, which also was described by Karl et al. (1993). The wind-temperature relationship may not be as strong at regional scales, however. The southeastern United States has experienced decreasing temperature maxima (Karl et al. 1993, Easterling et al. 1997), which should lead to reduced maximum winds by decreasing the nearsurface lapse rate. Instead, maximum wind speeds are increasing in this region (Fig. 2).

The relationship between surface temperature and vertical mixing may be different at night as the surface becomes decoupled from the lower atmosphere. Although the surface inversion suppresses turbulence, the resulting near-surface wind shear may promote it (Stull 1988). Rising minimum temperatures may weaken the nighttime inversion, reducing the nearsurface wind speed gradient and its mechanically produced turbulence. The result would be decreased nighttime wind speeds, as observed in these data.

\subsection{Cyclonic and anticyclonic activity}

Surface winds also are related to synoptic-scale wind patterns (cyclones and anticyclones). The link between 
local surface winds and continental-scale pressure patterns appears to be stronger in some parts of the country than in others (Klink 1999). Surface cyclone and anticyclone frequencies and intensities themselves may be related to large-scale surface temperature trends (Agee 1991), though these relationships can be different in different parts of the country (Angel \& Isard 1998).

Several authors have documented trends in cyclone and anticyclone frequencies (and sometimes intensities) within the United States (e.g. Zishka \& Smith 1980, Harman 1987, Agee 1991, Changnon et al. 1995, Davis et al. 1997, Angel \& Isard 1998). These authors identify a decrease in cyclone and anticyclone activity from 1961 until the late 1970s to early 1980s. Subsequently, cyclone activity increased through 1990. It is less clear whether anticyclone frequency or intensity underwent a change in the 1980s (Harman's data extend only to 1979), though Davis et al. (1997) hint at such a change by documenting an increase in the frequency of the winter- and summer-dominant modes of the North Atlantic subtropical high beginning in the early 1980s.

Cyclone and anticyclone frequencies have been decreasing in the United States for most of the period included in this study, with decreased cyclone frequency typically accompanied by increased intensity (Zishka \& Smith 1980, Angel \& Isard 1998). It is not clear whether fewer, more intense cyclones-as opposed to more frequent but weaker activity-would necessarily increase mean speeds or affect maxima and minima differently. Although a decrease in mean monthly wind speeds is consistent with decreasing cyclone frequency, it is difficult at present to make direct comparisons between the overall increase in monthly mean maximum speeds and the decrease in minimum speeds and the observed cyclone/anticyclone trends in the United States.

\subsection{Urbanization}

Urbanization affects surface wind speed in 2 ways. The urban heat island enhances urban-to-rural temperature (and thus pressure) gradients and increases urban wind speeds, while the higher surface roughness in cities as compared to rural areas acts to decrease urban wind speeds. Under low regional wind speeds, which are more common at night, the "heat island' effect typically is dominant so that urban wind speeds are enhanced compared to rural areas. The 'roughness' effect dominates when the large-scale flow is faster, which is typical of daylight hours (Bornstein \& J ohnson 1977, Lee 1979, Balling \& Cerveny 1987). As cities grow, then, their maximum wind speeds are reduced (roughness effect) and their minimum speeds are enhanced (heat island effect).

Overall trends in maximum and minimum wind speeds for 1961 to 1990 show slightly enhanced maxima and a larger reduction in minima, opposite what would be expected from increasing urbanization. In the southeastern United States, where mean minimum wind speeds generally are low (Fig. 4), nighttime urban enhancement might be more common. Minimum speeds in most months and at most stations in the region are decreasing, however, with a few exceptions (e.g. Atlanta GA, Miami FL) (Fig. 5). Similar patterns appear in the western United States, with most stations showing a decrease in minima during this period. Wind speeds at Philadel phia show trends that are most consistent with what would be expected from urban heat-island effects: for most months, maxima have decreased and minima have increased.

Some of the stations in this data set are in or near highly urbanized areas (Los Angeles, Chicago, Philadelphia, New York City) that probably have large urban-to-rural temperature gradients, but many (about $44 \%)$ are in or near cities with populations less than 100000 for which heat-island effects are likely to be smaller (e.g. Oke 1987). Only about $5 \%$ of the wind sites are in cities with fewer than 10000 residents, the threshold population for which urbanization biases have been identified in the temperature record (Karl et al. 1988). Wind speeds in urban areas probably are affected by changes not only in the population but also in the amount of urbanization surrounding wind sites. For example, census data show that between 1960 and 1990 the population of Philadelphia's urbanized area grew by about $16 \%$ while its areal extent increased by $95 \%$.

\subsection{Instrumentation, observation, and exposure biases}

Biases in instrument performance and changes in instrument type both may affect wind measurements. In his examination of wind speed records in the northeastern United States, DeGaetano (1998) discovered that reductions in the frequency of $3 \mathrm{knot}\left(1.5 \mathrm{~m} \mathrm{~s}^{-1}\right)$ wind reports and increases in the frequency of calm reports regularly occurred simultaneously; he speculated that this pattern was due to a deterioration in anemometer performance over time. Such a deterioration could partially account for the increased frequency of calm reports at many stations in this data set, though it is unclear whether instrument degradation would occur similarly (or simultaneously) at all stations. The type of anemometer used at a station also may change over time, which could introduce disconti- 
nuities into the wind record. Weather observation handbooks provide tables with which to correct wind speed measurements as a function of instrument type (cf. US Department of Commerce 1963, 1970, 1988), and presumably these corrections would reduce the effects of changing anemometer types.

Observation bias also may be present in wind speed records. At stations in the northeastern United States, DeGaetano (1998) described an apparent underreporting of light ( 1 and 2 knot) winds. He surmised that this bias was due to observers failing to use the Beaufort scale to estimate wind speeds that were below the starting speed of the anemometer. In addition, DeGaetano noted a tendency to round reported wind speeds to the nearest 2 or 5 knot increment. Underreporting of light winds could partially account for the increased frequency of calm winds that occurred at many stations in this data set, because using the Beaufort scale to estimate low wind speeds might be especially difficult at night. Rounding errors, on the other hand, may introduce a small or even negligible bias since rounding 'up' and rounding 'down' should occur with equal frequency.

A third bias that could affect wind measurements is changes in anemometer exposure. Exposure differences resulting from changes in anemometer height largely can be compensated by standardizing wind speeds to a common measurement height. Ideally this standardization should include stability corrections, but often such corrections are not implemented due to a lack of necessary data. Anemometer exposure also may be affected by changes in roughness at the measurement site. Most wind observation sites are located at airports, so changes in roughness over time may be expected to be small. To test this assumption, Shein (1995) reconstructed the history of development (and thus roughness changes) from 1961 to 1990 at windreporting stations in the midwestern United States. He found that most development at the sites was due to the addition of airport buildings or the extension of runways, and concluded that despite such changes the majority of the stations maintained good exposure to the near-surface wind field. Shein also noted, however, that the effects of airport development on wind speeds themselves could not be determined.

\section{SUMMARY AND CONCLUSIONS}

Mean monthly maximum and minimum surface wind speeds in the coterminous United States have similar spatial patterns, with lower values in the western and the southeastern states and higher speeds in the central and northeastern regions. In general, maxima and minima are largest in spring and smallest dur- ing the summer. Spatial and seasonal patterns for maximum and minimum speeds are similar to those observed for mean monthly values. Linear trends fit to mean monthly maximum speeds from 1961 to 1990 showed an increase during most of the year for most stations, while decreases in maxima were more common from February through May. In contrast, monthly minimum wind speeds decreased overall in all months of the year, with comparatively few stations showing increasing trends.

Surface winds are influenced by a variety of factors that range from global (hemisphere-spanning waves) to local scales (site-specific land-surface characteristics). Decreasing hemispheric temperature (and pressure) gradients may reduce mean wind speeds, while increasing maximum and minimum surface temperatures could differentially impact maximum and minimum winds by altering atmospheric stability and turbulent mixing. Changes in cyclone and anticyclone frequencies and intensities may also affect surface wind speeds, though it is not clear if maximum and minimum speeds would be affected differently. Increasing urbanization acts to decrease maximum winds but to increase minimum values. Instrumentation, observation, and exposure biases may cause spurious trends in maximum and minimum wind speeds.

The degree to which climatological and other variables can enhance or diminish surface wind speeds is not completely understood. Continental-scale decreases in cyclone frequency may not result in decreased surface wind speeds, especially if the intensity of cyclones increases at the same time, and regional-scale trends in cyclone frequency may not correspond to continental-scale trends. In addition, it is difficult to know the degree to which urbanization will magnify or reduce wind speeds, especially when its effects are superimposed on larger-scale climatological variations. Deterioration in anemometer performance, observation bias in wind speed reports, and increases in surface roughness may artificially enhance a trend toward decreases in minimum wind speeds, but the effects of such biases on maximum speeds is less obvious.

This exploratory analysis has shown that trends do exist in maximum and minimum wind speeds at sites across the coterminous United States, but attribution of causes is problematic. Additional studies are needed to help unravel how the observed $30 \mathrm{yr}$ trends may be related to large-scale and local features. The relationship between surface wind speed and surface temperature (exclusive of the urban heat island) needs further examination, as does that between surface and upperair winds and cyclone/anticyclone activity; regional analyses should complement continental-scale studies. Finer temporal resolution (daily or hourly values) may 
be useful for such studies (e.g. Shein 1995). Paired urban-rural wind speed observations in a variety of climatological settings are needed to help determine how local, regional, and global factors affect wind speeds in urban areas. Site-specific factors such as station relocation, instrumentation changes, and changes in observing practice (e.g. DeGaetano 1998) need further examination as possible sources of bias in the wind speed record.

Acknowledgements. Conversation with K. A. Shein prompted me to undertake this analysis. I thank R. H. Skaggs for valuable discussion during the course of this work; J. F. Hart and M. B. Lindberg for providing population statistics; and K. J. Lawless, K. A. Shein, R. H. Skaggs, and the reviewers for helpful comments on the manuscript. R. Carlyon, D. Perry, and G. Spoden provided valuable assistance in reconstructing National Weather Service wind observing and reporting procedures. I thank M. B. Lindberg and the University of Minnesota Cartography Laboratory for preparing the final figures. Portions of this research were supported by the Minnesota Supercomputer Institute.

\section{LITERATURE CITED}

Agee EM (1991) Trends in cyclone and anticyclone frequency and comparison with periods of warming and cooling over the Northern Hemisphere. J Clim 4:263-267

Angel JR, Isard SA (1998) The frequency and intensity of Great Lake cyclones. J Clim 11:61-71

Balling RC J r, Cerveny RS (1987) Long-term associations between wind speeds and the urban heat island of Phoenix, Arizona. J Clim Appl M eteorol 26:712-716

Bornstein RD, J ohnson DS (1977) Urban-rural wind velocity differences. Atmos Environ 11:597-604

Changnon D, Noel J, Maze LH (1995) Determining cyclone frequencies using equal-area circles. Mon Weather Rev 123:2285-2294

Davis RE, Hayden BP, Gay DA, Phillips WL, J ones GV (1997) The North Atlantic subtropical anticyclone. J Clim 10: 728-744

DeGaetano AT (1997) A quality-control routine for hourly wind observations. J Atmos Oceanic Technol 14:308-317

DeGaetano AT (1998) Identification and implications of biases in US surface wind observation, archival, and summarization methods. Theor Appl Climatol 60:151-162

Easterling DR, Horton B, J ones PD, Peterson TC, Karl TR, Parker DE, Salinger MJ , Razuvayev V, Plummer N, J amason P, Folland CK (1997) M aximum and minimum temperature trends for the globe. Science 277:364-367

Efron G, Tibshirani R (1986) Bootstrap methods for standard errors, confidence intervals, and other measures of statistical accuracy. Stat Sci 1:54-77

Harman J R (1987) M ean monthly North A merican anticyclone frequencies, 1950-79. M on Weather Rev 115:2840-2848

J ones PD (1994) Hemispheric surface air temperature variations: a reanalysis and an update to 1993. J Clim 7: 1794-1802

Editorial responsibility: Laurence Kalkstein, Newark, Delaware, USA
Karl TR, Diaz HF, Kukla G (1988) Urbanization: its detection and effect in the United States climate record. J Clim 1: 1099-1123

Karl TR, J ones PD, Knight RW, Kukla G, Plummer N, Razuvayev V, Gallo KP, Lindseay J , Charlson RJ, Peterson TC (1993) Asymmetric trends of daily maximum and minimum temperature. Bull Am M eteorol Soc 74:1007-1023

Klink K (1999) Climatological mean and interannual variance of United States surface wind speed, direction, and velocity. Int J Climatol 19:471-488

Lee DO (1979) The influence of atmospheric stability and the urban heat island on urban-rural wind speed differences. Atmos Environ 13:1175-1180

Nicholls N, Gruza GV, J ouzel J , Karl TR, Ogallo LA, Parker DE (1996) Observed climate variability and change. In: Houghton JT, Meira Filho LG, Callander BA, Harris N, Kattenberg A, Maskell K (eds) Climate change 1995: the science of climate change. Cambridge University Press, Cambridge, p 133-192

NOAA (National Oceanic and Atmospheric Administration) (1993) Local climatological data - annual summaries for 1993 (5 vols). National Climatic Data Center, Asheville, NC

NREL (National Renewable Energy Laboratory) (1992) National solar radiation data base (1961-1990) user's manual. National Climatic Data Center, A sheville, NC

NREL (National Renewable Energy Laboratory) (1993) Solar and meteorological surface observation network 1961-1990, ver 1.0 (3 vol CD set). National Climatic Data Center, Asheville, NC

Oke TR (1987) Boundary layer climates, 2nd edn. Routledge, New York

Peterson EW, Hennessey JP J r (1978) On the use of power laws for estimates of wind power potential. J Appl M eteorol 17:390-394

Shein KA (1995) Wind speed variability in the midwestern United States 1961-1990: implications for wind energy assessment. MA thesis, Indiana University, Department of Geography, Bloomington, IN

Stull RB (1988) An introduction to boundary layer meteorology. Kluwer Academic Publishers, Dordrecht

Touma J S (1977) Dependence of the wind profile power law on stability for various locations. J Air Pollut Control Assoc 27:863-866

US Department of Commerce (1963) History of weather bureau wind measurements. Key to meteorological records documentation no. 3.151. US Government Printing Office, Washington, DC

US Department of Commerce (1970) Federal meteorological handbook no. 1, surface observations (supersedes 7th edn of WBAN circular N). US Government Printing Office, Washington, DC

US Department of Commerce (1988) Federal meteorological handbook no. 1, surface observations (Office of the Federal Coordinator for M eteorological Services and Supporting Research FCM-H1-1988). US Government Printing Office, Washington, DC

Zishka KM, Smith PJ (1980) The climatology of cyclones and anticyclones over North America and surrounding ocean environs for J anuary and J uly, 1950-77. M on Weather Rev 108:387-401

Submitted: J uly 1, 1998; Accepted: J uly 29, 1999

Proofs received from author(s): N ovember 9, 1999 